\title{
INTERNALISASI NILAI-NILAI PANCASILA DALAM MENINGKATKAN KESADARAN BELA NEGARA PADA GENERASI MILENIAL
}

\author{
Shabika Azzaria Putri \\ Universitas Pembangunan Nasional Veteran Jakarta \\ Email: sazzaria123@gmail.com
}

\begin{abstract}
At this moment the Indonesian people has experienced many changes expected to the globalization change. With the varying developments in this stage of globalization, it suggests a trying for the Indonesian people to go on to appropriate up and adhere to the flow of innovation. In the present cycle of globalization, the position of Pancasila is absolutely highly remarkable in conduct to preserve the survival of the identity of the Indonesian societies, because the affect of globalization of borders between states seems invisible, so that various foreign cultures easily penetrate into community. The fundamental issue in this investigation is to internalize the values of Pancasila in developing consciousness of safeguarding the state in the millennial generation and struggles to internalize the values of Pancasila in enhancing awareness of fighting for the country in the millennial ages. In this view, the researcher used interview as data collection method, and backed by literature review on secondary documents. The results study, the relevance of internalizing the values of Pancasila because Pancasila has a serve and position in the nation and state and can develop appreciation of safeguarding the state by practicing Pancasila values in workaday life in order to keep the existence of the nation and state of Indonesia and reinforce awareness of maintaining the state, specifically the millennial generation. The development of state defense information is given lines to overcome understandings, ideologies, and cultures that are opposed to the identity values maintained by the Indonesian nation. The state defense is brought out on going support through education, training and socialization so that it can support the authority for the opportunity of defense systems.
\end{abstract}

Keywords: Pancasila, State Defense Awareness, Millennial Generation.

\begin{abstract}
Abstrak
Pada saat ini kehidupan masyarakat Indonesia sudah banyak mengalami pergeseran karena pengaruh globalisasi. Dengan pergeseran perubahan di era globalisasi ini memberi tantangan bagi masyarakat Indonesia untuk terus membuka diri dan mengikuti arus perubahan baik dalam keadaan siap dan tidak siap. Pada era globalisasi saat ini, peran Pancasila tentu penting sekali guna tetap memelihara eksistensi kepribadian bangsa Indonesia, sebab adanya pengaruh dari globalisasi batasan-batasan diantara negara seakan tidak terlihat, sehingga bermacam-macam budaya asing mudah masuk ke dalam masyarakat. Pokok permasalahan dalam penelitian ini dibutuhkan internalisasi nilai-nilai Pancasila dalam meningkatkan kesadaran bela negara pada generasi milineal dan upaya internalisasi nilai-nilai Pancasila dalam meningkatkan kesadaran bela negara pada generasi milineal. Dalam penelitian ini, peneliti menggunakan teknik pengumpulan data yakni, wawancara dan ditunjang dengan studi pustaka pada dokumen sekunder. Hasil dari penelitian ini, menunjukkan pentingnya internalisasi nilai-nilai Pancasila, sebab Pancasila mempunyai fungsi dan kedudukan dalam bangsa dan negara dan dapat meningkatkan kesadaran bela negara pada warga negara khususnya generasi milienial. Pembinaan kesadaran bela negara diberi arah untuk mengatasi paham, ideologi, budaya yang bertentangan dengan nilai-nilai
\end{abstract}


kepribadian yang dimiliki oleh bangsa Indonesia. Bela negara secara berkesinambungan dapat dilakukan melalui pendidikan, latihan dan sosialisasi, untuk memperkokoh landasan terhadap ketersediaan sumber daya pertahanan.

Kata Kunci: Pancasila, Kesadaran Bela Negara, Generasi Milineal.

\section{Pendahuluan}

Negara Indonesia merupakan sebuah negara kepulauan yang mempunyai cakupan wilayah yang sangat luas. Pulau-pulau di Indonesia sangatlah banyak mencapai ribuan pulau yang terbentang dari Sabang sampai dengan Merauke. Ribuan pulau itu ditempati oleh beraneka macam suku bangsa di Indonesia. Tiap suku bangsa mempunyai ciri khas pada budayanya sendiri sehingga Indonesia memiliki berbagai macam budaya yang patut untuk dijaga dan dikembangkan terus potensinya. ${ }^{1}$

Dahulu Indonesia pernah merasakan penjajahan yang dilakukan oleh bangsa Belanda dan Jepang, kedua Bangsa ini ingin menguasai negara Indonesia pada saat itu. Namun, keinginan penjajah tersebut sangat tidak disetujui oleh para pahlawan, ulama dan seluruh masyarakat bangsa Indonesia pada waktu itu. Maka, pada akhirnya para pahlawan banyak melakukan pengorbanan dan bertumpah darah untuk mempertahankan wilayah negara Indonesia dengan ikut berperang melawan para penjajah. Pengorbanan yang dilakukan pahlawan-pahlawan ini sudah sepatutnya kita sebagai generasi milineal menghargai mereka dengan mempunyai kesadaran bela negara yang tinggi terhadap negara Indonesia merupakan sebagai tempat tinggal kita baik langsung maupun tidak langsung. Meskipun, pada saat ini tantangan yang kita hadapi itu bukan ancaman fisik seperti perang yang dilakukan oleh para pahlawan, tetapi tantangan yang dihadapi generasi milineal cukup berat yakni, musuh dari bangsa sendiri dan juga persaingan dalam lingkup global. ${ }^{2}$

Pada saat ini kehidupan masyarakat Indonesia sudah banyak mengalami pergeseran dari lingkup dalam negeri menjadi lingkup luar, dikarenakan adanya pengaruh globalisasi. Globalisasi merupakan proses integrasi internasional terjadi sebab adanya pertukaran pandangan dunia, produk, pemikiran, serta berbagai bidang kebudayaan lainnya. Infrastruktur di bidang transportasi dan telekomunikasi yang mengalami kemajuan termasuk kemunculan telegraf dan internet sebagai salah satu penyebab utama dalam globalisasi yang semakin mendorong saling ketergantungan antara ekonomi dan budaya. Sehingga globalisasi ialah pemadatan

\footnotetext{
${ }^{1}$ Tuhana Taufiq Andrianto, Paradigma Baru Bela Negara Implementasi Dan Pengembangannya Di Era Globalisasi, (Yogyakarta: Global Pustaka Utama Yogyakarta, 2015), h. 1.

${ }^{2}$ Putu Ronny Angga Mahendra dan I Made Kartika, Memperkuat Kesadaran Bela Negara Dengan NilaiNilai Pancasila Dalam Perspektif Kekinian, Jurnal Pendidikan Kewarganegaraan Undiksha, Vol.8, No.3, 2020.
}

DIKTUM: Jurnal Syariah dan Hukum Volume 19 Nomor 1 Juli 2021 
dunia dan secara keseluruhan pemerkayaan kesadaran dunia. ${ }^{3}$ Dengan adanya pergeseran karena perubahan pada era globalisasi ini memberikan tantangan bagi masyarakat bangsa Indonesia untuk terus membuka diri dan mengikuti arus perubahan baik dalam keadaan siap maupun dalam keadaan tak siap. Setiap warga negara mempunyai kewajiban pada negara yakni, melakukan bela negara agar Negara Indonesia dapat melaksanakan tujuan dan fungsinya untuk memajukan kesejahteraan umum, mencerdaskan kehidupan bangsa dan ikut melaksanakan ketertiban dunia yang berdasarkan kemerdekaan, perdamaian abadi dan keadilan sosial. Tiap warga negara yang melaksanakan kewajiban ini, maka warga negara tersebut telah membantu fungsi dan tujuan bangsa Indonesia. ${ }^{4}$

Pancasila sebagai ideologi dan dasar Negara yang merupakan kesepakatan bapak pendiri bangsa saat Negara Indonesia didirikan dan sampai dengan saat ini pada era globalisasi, Negara Indonesia tetap berpegang teguh kepada Pancasila sebagai dasar negara. Pancasila sebagai dasar negara, harus menjadi pedoman negara dalam menghadapi beraneka macam tantangan globalisasi yang terus berkembang. Pada era globalisasi saat ini, peran Pancasila tentu penting sekali guna tetap memelihara eksistensi kepribadian bangsa Indonesia, sebab ada pengaruh dari globalisasi batasan-batasan diantara negara seakan tidak terlihat, sehingga bermacam-macam budaya asing mudah masuk ke dalam masyarakat. Dengan mudahnya masuk budaya asing ke masyarakat Indonesia menimbulkan dampak baik positif dan negatif. Oleh karena itu, perlunya menyaring secara baik hal-hal yang ditimbulkan dari dampak globalisasi tentunya globalisasi itu akan menjadi hal yang positif karena bisa memberikan tambahan wawasan juga menciptakan hubungan yang erat antar Bangsa dan Negara di Dunia, sementara dampak negatif dari globalisasi bisa membuat rusaknya moral bangsa dan eksistensi kebudayaan Indonesia. Hal ini, generasi milineal yang merupakan sebagai pilar bangsa diharapkan mempunyai kesadaran bela negara dengan tetap berpegang pada nilainilai budaya yang dimiliki oleh Indonesia meskipun berbagai budaya asing masuk ke Indonesia. ${ }^{5}$

Dengan semakin banyaknya masuk pengaruh asing ke negara Indonesia seperti kemajuan teknologi, zaman yang semakin modern dan globalisasi membuat

3 "Pengertian Globalisasi", <http://eprints.ums.ac.id/47004/3/BAB\%20I.pdf>, diakses pada tanggal 28 Desember 2020, pukul 15:00 wib; dikutip dari Roland Robertson, Globalization Social Theory and Global Culture, (London: Sage Publications Ltd, 1992).

${ }^{4}$ Putu Ronny Angga Mahendra dan I Made Kartika, Memperkuat Kesadaran Bela Negara Dengan NilaiNilai Pancasila Dalam Perspektif Kekinian, Jurnal Pendidikan Kewarganegaraan Undiksha, Vol.8, No.3, 2020.

${ }^{5}$ Eta Yuni Lestari, Miftahul Jannah, dan Putri Karima Wardanai, Menumbuhkan Kesadaran Nasionalisme Generasi Muda di Era Globalisasi Melalui Penerapan Nilai-Nilai Pancasila, Adil Indonesia Jurnal, Vol.1, No. 1, 2019.

DIKTUM: Jurnal Syariah dan Hukum Volume 19 Nomor 1 Juli 2021 
kesadaran bela negara semakin berkurang pada masyarakat terutama generasi milineal. Maka dari itu, perlunya pembinaan kesadaran bela negara pada generasi milineal di era globalisasi saat ini yang banyak dipengaruhi oleh budaya asing, salah satunya yaitu, dengan pengamalan nilai-nilai Pancasila dalam kehidupan sehari-hari. Oleh karena itu, berdasarkan dari latar belakang yang diuraikan diatas penulis tertarik untuk mengkaji sebagai penelitian terkait Internalisasi Nilai-Nilai Pancasila Dalam Meningkatkan Kesadaran Bela Negara Pada Generasi Milineal.

Apabila dilihat dari latar belakang masalah yang ada diatas, pokok permasalahan dalam penelitian ini adalah pentingnya dibutuhkan internalisasi nilainilai pancasila dalam meningkatkan kesadaran bela negara pada generasi milineal dan upaya internalisasi nilai-nilai pancasila dalam meningkatkan kesadaran bela negara pada generasi milineal.

\section{Metode}

Penelitian ini menggunakan pendekatan kualitatif. Peneliti menggunakan teknik pengumpulan data melalui wawancara dengan mengirimkan draft pertanyaan melalui email pada Pengacara yaitu Herly Hermawan yang bekerja di kantor Arsen \& Co. Law firm dan ditunjang studi pustaka dengan menggunakan dokumen sekunder yaitu bentuk dokumen yang ditulis dengan berdasarkan laporan, peristiwa ataupun berdasarkan dari cerita orang lain. ${ }^{6}$ Teknik analisis data yang digunakan dalam penelitian ini yaitu, analisis deskriptif kualitatif maksudnya melakukan pengolahan dan menyajikan data serta melakukan analisis terhadap data kualitatif, dengan menggabungkan data-data yang diperoleh dari bermacam-macam sumber, baik hasil wawancara, peraturan perundang-undangan, buku, jurnal dan sumber internet yang berhubungan dengan internalisasi nilai-nilai pancasila dalam meningkatkan kesadaran bela negara pada generasi milineal. Data-data tersebut dianalisa untuk menarik kesimpulan.

\section{Hasil dan Pembahasan}

\section{Urgensi Pembinaan Kesadaran Bela Negara di Era Globalisasi}

Pembinaan merupakan proses penggunaan manusia, alat peralatan, uang, waktu, metode dan sistem yang didasarkan pada prinsip tertentu dengan tujuan guna melakukan pencapaian yang sudah ditentukan dengan daya dan hasil yang sebesarbesarnya. ${ }^{7}$ Kemudian secara umum mengenai pembinaan merupakan adanya rencana dalam melakukan suatu kegiatan untuk menggapai tujuan yang sudah ditentukan

${ }^{6}$ Rada, “Teknik Pengumpulan Data”, <https://dosenpintar.com/teknik-pengumpulan-data/>, diakses pada tanggal 29 Desember 2020, pukul 18:40 wib.

${ }^{7}$ Musanef, Manajemen Kepegawaian di Indonesia, (Jakarta: Haji Masagung, 1991), h.11.

DIKTUM: Jurnal Syariah dan Hukum

Volume 19 Nomor 1

Juli 2021 
sebelumnya, pembinaan secara studi kasus umumnya dilaksanakan supaya manusia yang sudah baik menjadi lebih baik lagi, maksud pembinaan dalam artian ini adalah lebih merubah karakter seseorang ke arah tujuan yang akan dicapai. Lalu arti dari kesadaran menurut umum ialah adanya rasa sadar maupun kepekaan terhadap sekitar lingkungan, suatu kesadaran bisa kita lihat dan ketahui saat seseorang mematuhi aturan dan norma yang berlaku di dalam kehidupan masyarakat. ${ }^{8}$

Kesadaran bela negara merupakan hal yang penting dan utama guna kelangsungan di masa yang akan datang bagi Bangsa dan Negara. Kemudian, kesadaran warga negara dapat dilihat saat terciptanya kesadaran dalam upaya bela negara. Terciptanya suatu bela negara saat warga negara telah melaksanakan dengan baik hak dan kewajiban dalam upaya bela negara. Warga negara yang melaksanakan hak dan kewajiban akan menjadi masukan yang penting dan besar untuk bangsa dan negara dalam rangka memperjuangkan segenap tumpah darah, kedaulatan dan wilayah Indonesia. Dalam Undang-Undang Dasar Tahun 1945 adanya ketentuan yang mengatur tentang upaya bela negara tercantum dalam Pasal 30 ayat $(1)^{9}$ bahwa tiap-tiap warga negara berhak dan wajib ikut serta dalam usaha pertahanan dan keamanan negara serta tercantum dalam Pasal 27 ayat (3) ${ }^{10}$ bahwa Setiap warga negara berhak dan wajib ikut serta dalam upaya pembelaan negara.

Upaya kesadaran bela negara dilakukan secara terus-menerus di dalam pembinaan kesadaran bela negara yang merupakan tujuan guna menciptakan tiap warga negara memiliki rasa kesadaran, pemahaman, dan kepercayaan dalam hak dan kewajiban bela negara. Indonesia merupakan bangsa dengan adanya keinginan usaha untuk maju dan unggul di dalam setiap kelangsungan hidup di peradaban. Majunya suatu peradaban bisa terlihat dan terwujud saat warga negara melakukan hak dan kewajibannya dengan baik, hal yang diwasiatkan oleh pendiri bangsa Indonesia yaitu Founding Father adalah warga negara dan bangsa yang baik, damai, sejahtera, dan juga adil, hal ini tertuang dalam Pembukaan UUD Tahun 1945. ${ }^{11}$

Bela negara memiliki definisi yaitu, suatu tekad, perilaku serta tindakan yang dilakukan oleh warga negara secara teratur, terpadu, menyeluruh, dan berlanjut dilandasi oleh rasa cinta pada tanah air Indonesia. Setiap warga negara wajib melakukan bela negara yang disertai dengan adanya kesadaran berbangsa dan

8 "Bab II Kajian Teori dan Kerangka Pemikiran”, <http://repository.unpas.ac.id/49952/5/BAB\%20II.pdf>,diakses pada tanggal 31 Januari 2021, pukul 12:01 wib.

${ }^{9}$ Redaksi Kawan Pustaka, UUD 45 \& Perubahannya Susunan Kabinet RI Lengkap (1945-2014), (Jakarta: PT. Kawan Pustaka, 2004), h. 31.

${ }^{10}$ Ibid., h.26

11 "Bab II Kajian Teori dan Kerangka Pemikiran", <http://repository.unpas.ac.id/49952/5/BAB\%20II.pdf>,diakses pada tanggal 31 Januari 2021, pukul 12:01 wib.

DIKTUM: Jurnal Syariah dan Hukum Volume 19 Nomor 1 Juli 2021 
bernegara Indonesia. Pada hakikatnya kesadaran bela negara adalah kesediaan tiap warga negara untuk ingin berbakti kepada bangsa dan negara serta rela berkorban yang bertujuan untuk melakukan bela negara. ${ }^{12}$

Pendidikan Pendahuluan Bela Negara disingkat dengan PPBN adalah pendidikan dasar bela negara guna menumbuhkan rasa cinta pada Bangsa dan Negara Indonesia, adanya kesadaran pada Bangsa dan Negara, yakin terhadap ideologi Pancasila serta rela berkorban bagi Bangsa dan Negara Indonesia. Pembinaan kesadaran bela negara dimana oleh kementerian pertahanan dilakukan pelaksanaan terkait pendidikan dan pelatihan bela negara untuk organisasi-organisasi yang terdapat di wilayah Indonesia seperti organisasi kepemudaan, organisasi masyarakat dan tokoh-tokoh adat. Kemudian, di lingkungan sekolah, profesi atau pekerjaan dan lingkungan pemukiman warga juga diberikan pendidikan kesadaran bela negara kepada tokoh-tokoh penting dan mempunyai pengaruh di lingkungannya tersebut.

Sangat urgen, mengingat dunia teknologi sudah tidak menempati ruang dan waktu lagi. Jarak sudah tidak menjadi penghalang, arus informasi yang positif dan negatif sangat deras melalui teknologi internet. Setiap orang kapan pun dimanapun dapat mengakses informasi-informasi negatif (hoax). Jadi, harus lah bijak dalam penggunaan teknologi pada era globalisasi ini. ${ }^{13}$

Tujuan dilaksanakan pembinaan kesadaran bela negara adalah guna menumbuhkembangkan kesadaran bela negara pada tiap warga negara terhadap bangsa dan negara dengan melalui sosialisasi, pemberian motivasi agar warga negara mencintai negaranya sendiri dan tidak lupa rela berkorban pada bangsa dan negara juga bisa dengan pendekatan. Cara-cara tersebut berjalan dengan baik apabila telah terlihat dari perilaku warga negara yang memiliki rasa cinta kepada tanah air, menunjukkan kelebihan dalam melakukan upaya bela negara serta memahami apa itu bela negara yang sebenarnya.

\section{Pentingnya Kesadaran Bela Negara Pada Generasi Milineal}

Letak geografis Indonesia itu strategis yang memiliki potensi berbagai ancaman, dimana bentuk ancaman terhadap kedaulatan negara terjadi sekarang makin bersifat multidimensional dilihat dari semakin berkembangnya IPTEK (Ilmu Pengetahuan, Teknologi, Informasi dan Komunikasi). Hal ini, yang menjadikan tiap warga negara dituntut untuk dapat mengatasi berbagai ancaman, tantangan dan hambatan baik itu berasal dari dalam negeri maupun luar negeri. Terkait dengan hal ini perlu adanya pemahaman yang baik dalam hal kesadaran bela negara, kemudian

12 Tuhana Taufiq Andrianto, Paradigma Baru Bela Negara Implementasi Dan Pengembangannya Di Era Globalisasi, (Yogyakarta: Global Pustaka Utama Yogyakarta, 2015), h. 28.

${ }^{13}$ Hasil wawancara dengan Bapak Herly Hermawan sebagai Pengacara di Kantor Arsen \& Co. Law firm, pada tanggal 29 Januari 2021.

DIKTUM: Jurnal Syariah dan Hukum Volume 19 Nomor 1 Juli 2021 
pemahaman kesadaran bela negara itu diperlukan dengan cara berperan dan aktif sebagai warga negara guna menjaga kedaulatan Negara Kesatuan Republik Indonesia (NKRI). Dasar hukum tentang bela negara seperti yang sudah dijelaskan di atas tercantum dalam Pasal 27 ayat (3) dan Pasal 30 ayat (1) pada UUD Tahun 1945. ${ }^{14}$

Kemudian, untuk bisa menjalankan hal-hal yang terkait dalam UUD 1945 dimana bisa disampaikan dalam aktifitas berupa kegiatan yang ada hubungannya dengan bela negara pada seluruh masyarakat, karena seperti yang harus kita ketahui kewajiban bela negara bukan saja dilakukan oleh tenaga kerja bidang militer saja melainkan kita sebagai generasi milinial juga bisa, jadi untuk melakukan bela negara tidak harus yang bidang militer saja. Lalu, ancaman terdiri dari dua macam yaitu, ancaman militer dan ancaman non-militer. Ancaman militer ${ }^{15}$ adalah ancaman yang memiliki beragam karakter yang bisa berupa jenis ancaman bersifat terorganisasi dengan menggunakan senjata yang dinilai adanya kemampuan untuk membahayakan kedaulatan, keutuhan dan keselamatan pada warga, Bangsa dan Negara.

Ancaman ini bisa berupa agresi, pelanggaran wilayah, pemberontakan senjata, sabotase, aksi teror bersenjata, ancaman keamanan laut dan udara, dan juga konflik komunal. Lalu, Ancaman non-militer ${ }^{16}$ yaitu, suatu ancaman yang menggunakan penyebab-penyebab yang bukan militer (non-militer) yang dinilai mempunyai kemampuan bisa membahayakan bagi kedaulatan negara, keutuhan wilayah negara serta keselamatan segenap bangsa. Contoh-contoh ancaman nonmiliter yaitu the brain war dalam bentuk konflik ideologi, adanya perbedaan dalam keunggulan, persaingan daya cipta dalam percaturan ekonomi, teknologi, ilmu pengetahuan dll.

Persoalan bela negara selama negara ini berdiri tetap sangat relevan dibutuhkan. Apalagi era milineal sekarang ini, ancaman, gangguan, hambatan dan tantangan pun semakin kompleks. Pesatnya teknologi digital semakin rumit pula ancaman terhadap negaranya. Bukan lagi peperangan dengan senjata secara fisik, namun melalui budaya, seni, ilmu pengetahuan, teknologi, dll. Membekali generasi milenial dengan kesadaran bela negara menjadi sangat elevan dan penting. Karena di pundak anak-anak muda milineal lah negara ini di bebankan. Sangat penting, karena kewajiban setiap warga negaralah untuk membela negaranya agar ketahanan sebuah negara kuat. ${ }^{17}$

14 Administrator, "Bela Negara dan Peran Serta Warga Negara Membangun Negeri", $<$ https://abnri.com/2020/03/20/bela-negara-dan-peran-serta-warga-negara-membangun-negeri-2/>, diakses pada tanggal 31 Januari 2021, pukul 16:26 wib.

${ }^{15}$ Ibid.,

${ }^{16}$ Ibid., h. 42.

${ }^{17}$ Wawancara dengan Bapak Herly Hermawan sebagai Pengacara di Kantor Arsen \& Co. Law firm, pada tanggal 29 Januari 2021.

DIKTUM: Jurnal Syariah dan Hukum Volume 19 Nomor 1 Juli 2021 
Menurut Dirjen Pothan Kemhan RI yaitu Bonda Tiara Sofyan yang mengatakan bahwa tiap warga negara harus ikut serta melakukan upaya bela negara dimana dalam rangka memperkuat pertahanan nasional, sebab membela negara merupakan hak dan kewajiban yang harus dimiliki tiap warga negara sebagaimana tercantum dalam Pasal 27 ayat (3) dan Pasal 30 ayat (1) UUD 1945. Kemudian, seperti yang dikatakan oleh beliau, bahwa bela negara bisa dituangkan dalam kehidupan seperti menjalani peran profesi yang dilakukan oleh tiap warga negara. Dalam menjalankan profesinya tersebut warga negara harus menjalankannya dengan bekerja keras sesuai dengan profesinya sebagai abdi negara, selain bekerja keras juga berbuat hal-hal baik, rela berkorban dan rasa nasionalisme (cinta pada tanah air). ${ }^{18}$

Maka dari itu, kesadaran bela negara itu penting bagi tiap warga negara karena sudah jelas tertuang dalam Undang-Undang Dasar Tahun 1945, Pasal 27 ayat (3) dan Pasal 30 ayat (3) bahwa tiap warga negara harus ikut serta dalam melakukan bela negara guna menjaga dan memelihara kelangsungan hidup bangsa dan negara Indonesia. Dimana tidak hanya warga negara yang berprofesi militer saja namun, yang non-militer pun bisa melakukan bela negara. Dalam bela negara terdapat nilainilai yang terkandung di dalamnya yaitu, rasa cinta pada tanah air, rasa kesadaran berbangsa dan bernegara, yakin bahwa ideologi negara kita itu ialah Pancasila, tidak mudah menyerah dan rela berkorban serta mempunyai kemampuan awal bela negara. Pada intinya, perlunya kesadaran bela negara untuk diterapkan dalam kehidupan sehari-hari, dapat melalui pembelajaran, sosialisasi dan motivasi.

\section{Pentingnya Nilai-Nilai Pancasila}

Nilai merupakan sarana pelatihan untuk kita contohnya seperti nilai pengalaman pribadi semata, nilai ide platonik, esensi. ${ }^{19}$ Nilai adalah suatu hal yang berharga, bermutu, menunjukkan kualitas dan memiliki kegunaan bagi manusia. Sesuatu yang bernilai mempunyai arti sesuatu itu berharga atau berguna bagi manusia dalam kehidupannya. ${ }^{20}$

Dalam etimologis istilah "Pancasila" asalnya dari bahasa Sanskerta. Pendapat mengenai Pancasila disampaikan salah satunya oleh Muhammad Yamin, Pancasila mempunyai dua macam arti secara leksikal yakni, panca artinya lima, syila vocal i pendek artinya batu sendi, syiila vocal I panjang artinya peraturan tingkah laku

18 "Pentingnya Bela Negara Bagi Seluruh Rakyat Indonesia",
<https://pontianak.tribunnews.com/2019/10/06/pentingnya-bela-negara-bagi-seluruh-rakyat-
indonesia?page=all>, diakses pada tanggal 31 Januari 2021, pukul 17:18 wib.
${ }^{19}$ Munir, Umi Salamah, Suratman, Pendidikan Pancasila, (Malang: Madani Media (Kelompok Intrans
Publishing), 2016, Cet. Ketiga, h. 139; dikutip dari Sofyan Sauri, Nilai <http://file.upi.edu/>, diakses
pada tanggal 21 Februari 2011.
${ }^{20}$ Ibid., dikutip dari <http://herwanparwiyanto.staff.uns.ac.id/>,diakses pada tanggal 21 Februari 2011. DIKTUM: Jurnal Syariah dan Hukum

Volume 19 Nomor 1 Juli 2021 
baik, yang penting atau yang senonoh. ${ }^{21}$ Kemudian, kata-kata itu diserap ke dalam Bahasa Indonesia yakni, Susila yang memiliki kaitan dengan moralitas. Jadi, karena hal tersebut dalam etimologis Panca Syila mempunyai makna berbatu sendi lima/secara harfiah artinya dasar yang mempunyai lima unsur. Dari penjelasan yang sudah diuraikan di atas, maka arti Pancasila secara etimologis adalah sebagai dasar/landasan hidup yang jumlahnya lima unsur ataupun mempunyai lima unsur.

Nilai-nilai Pancasila dapat dikategorikan menjadi dua jenis yaitu, nilai dasar dan nilai instrumental. Nilai-nilai dasar bersifat abstrak dan normatif. Karena bersifat abstrak dan normatif dimana pada isinya belum bisa untuk dioperasionalkan. Supaya bisa bersifat operasional dan eksplisit, perlu dijabarkan ke dalam nilai instrumental. Nilai instrumental contohnya yaitu UUD 1945 dan Peraturan Perundang-undangan yang lainnya. Sebagai nilai dasar, nilai-nilai tersebut menjadi sumber nilai, maksudnya dengan bersumber pada kelima nilai dasar dapat dibuat dan dijabarkan nilai-nilai instrumental penyelenggaraan negara Indonesia. ${ }^{22}$

Seperti yang dinyatakan dalam pembukaan UUD 1945 alinea IV bahwa Pancasila merupakan sebagai nilai dasar dan dijabarkannya itu sebagai nilai instrumental. Pada nilai dasar tidak berubah dan juga tidak boleh diubah lagi. Meskipun, pentingnya nilai dasar yang tercantum dalam pembukaan UUD 1945 itu yang bersifat belum operasional, dengan maksud sebagai warga negara kita belum dapat menjabarkannya dengan langsung pada kehidupan sehari-hari. ${ }^{23}$

Penjelasan UUD 1945 menunjuk adanya undang-undang yang berperan sebagai pelaksanaan hukum dasar tertulis itu. Nilai-nilai dasar yang terdapat dalam pembukaan UUD 1945 perlu dilakukan penjabaran lebih lanjut. Penjabaran tersebut sebagai arahan guna kehidupan nyata. Lalu penjabaran tersebut diberi nama Nilai Instrumental, nilai ini harus tetap mengacu pada nilai-nilai dasar yang dijabarkannya. Dengan penjabaran nilai itu bisa dilakukan dengan cara yang kreatif dan dinamis dimana dalam berbagai bentuk yang baru untuk mewujudkan semangat yang sama dan juga dalam batas-batas yang dimungkinkan oleh nilai dasar itu. Penjabaran itu tidak boleh bertentangan dengan nilai-nilai dasarnya. ${ }^{24}$

Penjabaran dari nilai-nilai dasar itu yaitu sebagai berikut: Nilai Ketuhanan, mempunyai maksud adanya pengakuan akan kebebasan untuk memeluk agama, kemudian menghormati kemerdekaan beragama, tidak adanya unsur paksaan dan tidak berlaku tindakan diskriminatif antar umat beragama. Pendapat Amiruddin

21 "Bab II Landasan Teori”, <http://etheses.iainkediri.ac.id/1314/3/932131714_BAB\%20II.pdf>, diakses pada tanggal 31 Januari 19:09 wib; dikutip dari Kaelan Pendidikan Pancasila, (Yogyakarta: Paradigma, 2010), h.21.

${ }^{22}$ Munir, Umi Salamah, dan Suratman, Pendidikan Pancasila, (Malang: Madani Media, 2016), h.150.

${ }^{23}$ Ibid.,

${ }^{24}$ Herwan Parwiyanto, "Pancasila Sebagai Sumber Nilai", <http://herwaparwiyanto.staff.uns.ac.id/>, diakses pada tanggal 9 Januari 2021, pukul 17:00 wib.

DIKTUM: Jurnal Syariah dan Hukum Volume 19 Nomor 1 Juli 2021 
bahwa inti yang sangat penting dari Pancasila ialah unsur Ketuhanan Yang Maha Esa. Unsur Ketuhanan Yang Maha Esa merupakan jantung Pancasila dimana hasil pengamalan para pendahulu bangsa dengan atas keberadaan Allah SWT. ${ }^{25}$ Nilai Kemanusiaan, nilai kemanusiaan yang adil dan beradab mempunyai kandungan arti sikap dan perilaku sesuai dengan nilai-nilai moral dalam hidup bersama atas dasar tuntutan hati nurani dengan memperlakukan suatu hal yang sebagaimana mestinya. Nilai Persatuan, mengandung makna usaha kearah bersatu dalam kebulatan rakyat guna membina rasa nasionalisme dalam Negara Kesatuan Republik Indonesia. Persatuan Indonesia yang mengakui dan menghargai seluruhnya secara sekaligus pada keberagaman yang dipunyai oleh Bangsa Indonesia. Nilai Kerakyatan, makna yang terkandung adalah makna suatu pemerintahan dari rakyat, oleh rakyat, dan untuk rakyat dengan cara dilakukannya musyawarah mufakat melalui lembagalembaga perwakilan. Nilai Keadilan, mengandung makna sebagai dasar dan juga tujuan yaitu, tercapainya masyarakat Indonesia yang adil dan makmur baik secara lahiriah dan/atau batiniah.

\section{Pentingnya Internalisasi Nilai-Nilai Pancasila Dalam Meningkatkan Kesadaran Bela Negara Pada Generasi Milenial}

Internalisasi secara etimologis adalah menunjukkan suatu proses. Pada kaidah bahasa Indonesia akhiran-isasi memiliki definisi proses. Jadi, internalisasi dapat diartikan sebagai suatu proses. Pada Kamus Bahasa Indonesia, Internalisasi memiliki arti sebagai penghayatan, pendalaman, penguasaan, secara mendalam yang dilakukan dengan cara bimbingan, binaan dan lain sebagainya. ${ }^{26}$

Pancasila sebagai sumber dari segala sumber hukum, sebab sumber dari sumber hukum yang ada di Indonesia yaitu Pancasila. Negara Indonesia yang menjadi landasan idiilnya adalah Pancasila sementara UUD 1945 merupakan landasan konstitusionilnya. Kemudian, Pancasila mempunyai nilai-nilai kultural yang sebagai wujud kepribadian bangsa dan negara Indonesia. Nilai-nilai yang tercantum dalam Pancasila perlu diterapkan ke dalam rupa bentuk sikap dan tindakan pada masyarakat dimana arahannya dapat membentuk masyarakat yang sadar akan hukum yang berlaku serta mempunyai perilaku yang sesuai dengan nilainilai yang terkandung dalam Pancasila ${ }^{27}$ terutama generasi milineal saat ini banyak terdampak oleh perkembangan dan kemajuan globalisasi.

Selanjutnya, internalisasi dengan Pancasila memiliki hubungan yakni, adanya persamaan dalam usaha untuk menyadarkan, merubah pola pikir yang

$25<$ http://bataviase.co.id/>diakses pada tanggal 28 Desember 2020, pukul 17:10 wib.

${ }^{26}$ Depdikbud, Kamus Besar Bahasa Indonesia, Buku Satu, (Jakarta: Balai Pustaka Utama,1989), h.336.

27 Dwi Zahrah Imania, <https://www.researchgate.net/publication/330278649_Internalisasi_nilainilai_Pancasila_melalui_Pendidikan_Pancasila_dan_kewarganegaraan_dari_masa_ke_masa>, diakses pada tanggal 2 Februari 2021, pukul 17:11 wib.

DIKTUM: Jurnal Syariah dan Hukum Volume 19 Nomor 1 Juli 2021 
terbatas dalam artian maksudnya sempit dan terkadang tak bernalar. Agar bisa dapat lebih berperilaku menghormati, menghargai dan terima adanya suatu perbedaan antara ras, agama, suku yang beraneka ragam ada di negara Indonesia. Kemudian, supaya tidak bertindak semena-mena pada orang lain, serta untuk menjadi pondasi negara agar seseorang tidak mudah terpengaruh sesuatu yang sebenarnya belum diketahui kebenarannya. Lalu memahami mengemukakan pendapat dengan baik dimana mengetahui pokok masalah yang ada. ${ }^{28}$

Kedudukan dan fungsi Pancasila dalam Negara dan Bangsa Indonesia yaitu, Pertama, Pancasila sebagai identitas bangsa Indonesia merupakan konsekuensi dari proses inkulturasi dan perpaduan budaya (akulturasi). Pengertian inkulturasi adalah suatu cara dalam memadukan beraneka budaya di dalam kehidupan masyarakat yang berkembang secara dinamis. Lalu pembentuk identitas bangsa yaitu, agama, suku, ras, kebudayaan dan juga bahasa. ${ }^{29}$

Kedua, Pancasila sebagai Kepribadian Bangsa Indonesia, menurut Dewan Perancang Nasional mengenai kepribadian Indonesia merupakan karakteristik khas yang menyeluruh yang dipunyai oleh Bangsa Indonesia, dengan karakteristik khas tersebut menjadikan adanya pembedaan antara bangsa Indonesia dan bangsa lainnya. ${ }^{30}$ Pancasila sebagai kepribadian bangsa memiliki arti bahwa nilai-nilai yang terdapat dalam Pancasila yaitu, nilai ketuhanan, nilai kemanusiaan, nilai persatuan, nilai kerakyatan dan nilai keadilan diterapkan dalam sikap mental, tingkah laku serta perbuatan. Meski, nilai-nilai tersebut ada juga ada dalam ideologi negara lain akan tetapi lima sila itu bagi Indonesia mencerminkan kepribadian bangsa sebab diambil dari nilai-nilai yang hidup di masyarakat Indonesia dan dilaksanakan secara simultan. ${ }^{31}$

Ketiga, Pancasila sebagai Pandangan Hidup Bangsa, pandangan hidup mempunyai fungsi sebagai kerangka acuan baik untuk menata kehidupan sendiri dan dalam melakukan interaksi sesama manusia dalam kehidupan bermasyarakat beserta alam sekitarnya. ${ }^{32}$ Di dalam pergaulan hidup terkandung konsep dasar tentang

28 Mellynea Kezyta Negraheni, Internalisasi Nilai-Nilai Pancasila Pada Kalangan Pelajar, <https://www.researchgate.net/publication/329484898_INTERNALISASI_NILAINILAI_DALAM_P ANCASILA_PADA_KALANGAN_PELAJAR> diakses pada tanggal 2 Februari 2021, pukul 17:11 wib.

${ }^{29}$ Warsito, Internalisasi Nilai-Nilai Luhur Pancasila dalam Mata Kuliah Pendidikan Pancasila di Perguruan Tinggi, Jurnal, 2017.

${ }^{30}$ Munir, Umi Salamah, Suratman, Pendidikan Pancasila, (Malang: Madani Media (Kelompok Instrans Publishing, 2016), Cet. Ketiga, h. 38.

${ }^{31}$ Warsito, Internalisasi Nilai-Nilai Luhur Pancasila dalam Mata Kuliah Pendidikan Pancasila di Perguruan Tinggi, Jurnal, 2017.

${ }^{32}$ Munir, Umi Salamah, Suratman, Pendidikan Pancasila, (Malang: Madani Media (Kelompok Instrans Publishing, 2016), Cet. Ketiga, h. 39; dikutip dari Kaelan, Pendidikan Pancasila, (Yogyakarta: Penerbit Paradigma, 2003), h.107.

DIKTUM: Jurnal Syariah dan Hukum Volume 19 Nomor 1 Juli 2021 
kehidupan yang diimpi-impikan (cita-cita) oleh bangsa, terkandung pikiran-pikiran yang terdalam dan gagasan sesuatu bangsa tentang wujud hidup yang baik. Yang akhirnya, pandangan hidup suatu bangsa merupakan kristalisasi dari nilai-nilai yang dimiliki oleh bangsa kemudian diyakini kebenarannya dan menimbulkan tekad pada bangsa untuk mewujudkannya. Hal ini artinya nilai-nilai yang terkandung dalam Pancasila digunakan sebagai penuntun, petunjuk, dan pegangan guna mengatur tingkah laku dan sikap manusia (warga negara Indonesia) pada saat hidup dalam masyarakat, bangsa dan negara. ${ }^{33}$

Keempat, Pancasila sebagai jiwa bangsa Indonesia mempunyai pengertian, arti statis yang maksudnya tetap atau tidak berubah dan memiliki arti dinamis (bergerak), Jiwa tersebut diaplikasikan dalam tingkah laku, sikap, mental dan juga perbuatan. Hal ini mempunyai arti Pancasila menempel dengan erat pada kehidupan Bangsa Indonesia serta menentukan keberadaan (eksistensi) bangsa Indonesia. Seluruh kegiatan bangsa Indonesia didukung dengan semangat Pancasila. ${ }^{34}$ Terakhir, Pancasila sebagai perjanjian luhur Bangsa mempunyai arti bahwa nilai-nilai yang terkandung dalam Pancasila sebagai jiwa bangsa dan kepribadian bangsa yang telah disepakati oleh para pendiri bangsa. ${ }^{35}$

Menurut Presiden Pertama Republik Indonesia yaitu, Soekarno mengatakan bahwa Pancasila itu lahir dari jiwa bangsa Indonesia sebagai weltaenschaung (falsafah) Bangsa Indonesia. dengan pemahaman Ideologi dan nilai-nilai Pancasila, kita akan mampu menghadapi ancaman di era globalisasi dari dunia luar. ${ }^{36}$

Jadi, pentingnya internalisasi nilai-nilai Pancasila sebab Pancasila mempunyai fungsi dan kedudukan dalam bangsa dan negara serta dapat meningkatkan kesadaran bela negara pada warga negara dengan mengamalkan nilainilai Pancasila di dalam kehidupan sehari-hari guna mempertahankan eksistensi bangsa dan negara Indonesia serta memperkuat kesadaran bela negara pada warga negara khususnya generasi milineal yang sudah banyak terdampak oleh pengaruhpengaruh budaya asing (globalisasi).

\section{Upaya Internalisasi Nilai-Nilai Pancasila Dalam Meningkatkan Kesadaran Bela Negara Pada Generasi Milenial}

Realisasi nilai-nilai Pancasila dasar filsafat dari Bangsa Indonesia butuh secara perlahan dengan melalui bidang pendidikan baik sekolah, masyarakat dan

\footnotetext{
${ }^{33}$ Munir, Umi Salamah, Suratman, Pendidikan Pancasila, (Malang: Madani Media (Kelompok Instrans Publishing, 2016), Cet. Ketiga, h. 40.

${ }^{34}$ bid., h.38.

${ }^{35}$ Warsito, Internalisasi Nilai-Nilai Luhur Pancasila dalam Mata Kuliah Pendidikan Pancasila di Perguruan Tinggi, Jurnal, 2017.

${ }^{36}$ Hasil wawancara dengan Bapak Herly Hermawan sebagai Pengacara di Kantor Arsen \& Co. Law firm, pada tanggal 29 Januari 2021.
}

DIKTUM: Jurnal Syariah dan Hukum Volume 19 Nomor 1 Juli 2021 
keluarga sehingga dapat mewujudkan keinginan yang dicita-citakan oleh bangsa dan negara. Penjelasan mengenai internalisasi nilai-nilai dalam Pancasila yang menurut pendapat Kaelan yaitu, (2013:685) ${ }^{37}$, dimana dengan internalisasi nilai-nilai Pancasila akan didapatkan hal-hal yakni, ${ }^{38}$ Pengetahuan merupakan pengetahuan yang benar mengenai Pancasila dari segi nilai, norma dan praksisnya. Kemudian harus disesuaikan dengan kemampuan dan pengetahuan yang dimiliki oleh individu. Kesadaran, seringkali tahu akan keadaan yang dialami oleh diri sendiri. Ketaatan, seringkali dalam keadaan kesediaan guna memenuhi kewajiban lahir dan batin, dimana lahir asalnya dari luar seperti pemerintah sedangkan batin asalnya dari dalam (diri sendiri), Kemampuan kehendak, mempunyai kekuatan yang cukup mendorong agar melakukan perbuatan. Watak dan Hati Nurani dimana orang agar selalu berhatihati (mawas diri), yaitu: cara melakukan penilaian pada diri sendiri terkait dalam hal berbuat baik atau tidak berbuat baik dalam melaksanakan Pancasila dan memberi sanksi batin berupa pujian atau celaan pada diri sendiri ataupun sebelum melakukan perbuatan membuat pedoman Pancasila. Jika telah melakukan nantinya akan didapatkan kesiapan sendiri guna mengaktualisasikan Pancasila untuk selanjutnya akan merupakan keyakinan akan kebenaran. Demikian, akan mempunyai ketahanan ideologi berdasar pada keyakinan atas kebenaran Pancasila, sehingga dirinya akan merupakan asal dari kemampuan dengan tujuan untuk menjaga, mengamalkan, memelihara, mewariskan Pancasila dalam seluruh bidang kehidupan, apabila warga negara Indonesia sudah berperilaku demikian ini maka tiap warga negara Indonesia kelak akan memiliki kepribadian watak dan hati nurani sesuai dengan Pancasila sehingga akan terwujud masyarakat, bangsa dan negara Pancasila. ${ }^{39}$

Berdasar pada penjelasan uraian di atas, mengenai internalisasi nilai-nilai Pancasila adalah proses penanaman ideologi Bangsa pada warga negara sebagai langkah upaya dalam membentuk suatu kepribadian, cara berpikir, serta pola tingkah laku dalam berbagai bidang dalam kehidupan berbangsa dan bernegara. Pancasila sebagai falsafah bangsa Indonesia maka seluruh komponen bangsa harus melakukan penjagaan dan mengaktualisasikan terkait nilai-nilai Pancasila dalam kehidupan sehari-hari. Dengan mengaktualisasikan nilai-nilai Pancasila tersebut di dalam aspek kehidupan, hal ini menjadikan bangsa Indonesia yakin mengenai ideologi Pancasila

${ }^{37}$ Kaelan, Negara Kebangsaan Pancasila, (Yogyakarta: Paradigma Undang-Undang Dasar 1945 Republik Indonesia, 2013), h.685.

${ }^{38}$ Nurhadianto, Internalisasi Nilai-Nilai Pancasila Dalam Upaya Membentuk Pelajar Anti Narkoba, Jurnal Pendidikan Ilmu Sosial, Vol.23, No. 2, 2014.

${ }^{39}$ Nurhadianto, Internalisasi Nilai-Nilai Pancasila Dalam Upaya Membentuk Pelajar Anti Narkoba, Jurnal Pendidikan Ilmu Sosial, Vol.23, No. 2, 2014.

DIKTUM: Jurnal Syariah dan Hukum Volume 19 Nomor 1 Juli 2021 
mampu menopang semua elemen bangsa baik dari bidang politik, ekonomi, sosial, budaya dan sebagainya. ${ }^{40}$

Bela negara menurut pendapat Siahaan yaitu, salah satu pembentuk jati diri dan kepribadian bangsa Indonesia dimana mempunyai rasa tanggung jawab, menyadari sebagai warga negara akan hak dan kewajibannya, memiliki rasa cinta pada tanah air sehingga mampu menampilkan sikap patriotik dalam wujud bela negara. Jiwa patriotik untuk Bangsa dan Negara diterapkan dalam sikap sebagai warga negara dan yang sadar bela negara ialah membangun kekuatan bela negara dalam Sishanneg. ${ }^{41}$

Pembinaan kesadaran bela negara diberi arah untuk mengatasi paham, ideologi, budaya yang bertentangan dengan nilai-nilai kepribadian yang dimiliki oleh bangsa dan negara Indonesia. Dilakukannya bela negara secara berkesinambungan caranya melalui pendidikan, latihan dan sosialisasi sehingga bisa memperkokoh landasan terhadap ketersediaan sumber daya pertahanan. Dilaksanakannya pembinaan bela negara dengan melalui berbagai lingkungan yaitu, pendidikan, pemukiman warga, tempat kerja.

\section{Kesimpulan}

Pembinaan kesadaran bela negara dimana oleh kementerian pertahanan dilakukan pelaksanaan terkait pendidikan dan pelatihan bela negara untuk organisasi-organisasi yang terdapat di wilayah Indonesia seperti organisasi kepemudaan, organisasi masyarakat dan tokoh-tokoh adat. Kemudian, di lingkungan sekolah, profesi atau pekerjaan dan lingkungan pemukiman warga juga diberikan pendidikan kesadaran bela negara kepada tokoh-tokoh penting dan mempunyai pengaruh di lingkungannya tersebut. Tujuan dilaksanakan pembinaan kesadaran bela negara adalah guna menumbuhkembangkan kesadaran bela negara pada tiap warga negara terhadap bangsa dan negara dengan melalui sosialisasi, pemberian motivasi agar warga negara mencintai negaranya sendiri dan tidak lupa rela

${ }^{40}$ Rian Nurizka dan Abdul Rahim, Internalisasi Nilai-Nilai Pancasila Dalam Membentuk Karakter Siswa Melalui Budaya Sekolah, Elementary School Jurnal Pendidikan dan Pembelajaran Ke-SD-an, Vol.7, No.1.

${ }^{41}$ Johny Nofriady, Yusuf, H.M. Halkis, Internalisasi Nilai-Nilai Bela Negara Dengan Pendekatan Binter di Wilayah Kodim 0618/BS Kota Bandung, Jurnal Program Studi Univeristas Pertahanan; dikutip dari Timbul Siahaan, Bela Negara dan Kebijakan Pertahanan, (Jakarta: Puskom Publik Kemhan, 2016), h.11. 
berkorban pada bangsa dan negara juga bisa dengan pendekatan. Kesadaran bela negara itu penting bagi tiap warga negara karena sudah jelas tertuang dalam UndangUndang Dasar Tahun 1945, Pasal 27 ayat (3) dan Pasal 30 ayat (3) bahwa tiap warga negara harus ikut serta dalam melakukan bela negara guna menjaga dan memelihara kelangsungan hidup bangsa dan negara Indonesia. Dimana tidak hanya warga negara yang berprofesi militer saja namun, yang non-militer pun bisa melakukan bela negara. Dalam bela negara terdapat nilai-nilai yang terkandung di dalamnya yaitu, rasa cinta pada tanah air, rasa kesadaran berbangsa dan bernegara, yakin bahwa ideologi negara kita itu adalah Pancasila, tidak mudah menyerah dan rela berkorban serta mempunyai kemampuan awal bela negara.

Nilai adalah suatu hal yang berharga, bermutu, menunjukkan kualitas dan memiliki kegunaan bagi manusia. Kemudian, arti Pancasila secara etimologis adalah sebagai dasar/landasan hidup yang jumlahnya lima unsur ataupun mempunyai lima unsur. Seperti yang dinyatakan dalam pembukaan UUD 1945 alinea IV bahwa Pancasila merupakan sebagai nilai dasar dan dijabarkannya itu sebagai nilai instrumental. Pada nilai dasar tidak berubah dan juga tidak boleh diubah lagi. Pentingnya internalisasi nilai-nilai Pancasila sebab Pancasila mempunyai fungsi dan kedudukan dalam bangsa dan negara serta dapat meningkatkan kesadaran bela negara pada warga negara dengan mengamalkan nilai-nilai Pancasila di dalam kehidupan sehari-hari guna mempertahankan eksistensi bangsa dan negara Indonesia serta memperkuat kesadaran bela negara pada warga negara khususnya generasi milineal yang sudah banyak terdampak oleh pengaruh-pengaruh budaya asing (globalisasi). Internalisasi nilai-nilai Pancasila adalah proses penanaman ideologi bangsa pada warga negara sebagai langkah upaya dalam membentuk suatu kepribadian, cara berpikir, serta pola tingkah laku dalam berbagai aspek dalam kehidupan berbangsa dan bernegara. Pancasila sebagai falsafah bangsa Indonesia maka seluruh komponen bangsa harus melakukan penjagaan dan mengaktualisasikan terkait nilai-nilai Pancasila dalam kehidupan sehari-hari.

\section{Daftar Pustaka}

\section{Buku}

Kaelan, Pendidikan Pancasila. Yogyakarta: Paradigma, 2010.

Kaelan, Negara Kebangsaan Pancasila. Yogyakarta: Paradigma Undang-Undang Dasar 1945 Republik Indonesia, 2013.

Kaelan, Pendidikan Pancasila. Yogyakarta: Penerbit Paradigma, 2003.

Lexy J. Moleong, Metodologi Penelitian Kualitatif. Bandung: Remaja Rosda Karya, 1993.

DIKTUM: Jurnal Syariah dan Hukum Volume 19 Nomor 1 
Munir, Umi Salamah, Suratman, Pendidikan Pancasila. Malang: Madani Media (Kelompok Intrans Publishing), 2016.

Musanef, Manajemen Kepegawaian di Indonesia. Jakarta: Haji Masagung, 1991.

Redaksi Kawan Pustaka, UUD 45 \& Perubahannya Susunan Kabinet RI Lengkap (19452014). Jakarta: PT. Kawan Pustaka, 2004.

Roland Robertson, Globalization Social Theory and Global Culture. London: Sage Publications Ltd., 1992.

Timbul Siahaan, Bela Negara dan Kebijakan Pertahanan. Jakarta: Puskom Publik Kemhan, 2016.

Tuhana Taufiq Andrianto, Paradigma Baru Bela Negara Implementasi Dan Pengembangannya Di Era Globalisasi. Yogyakarta: Global Pustaka Utama Yogyakarta, 2015.

Depdikbud, Kamus Besar Bahasa Indonesia, Buku Satu. Jakarta: Balai Pustaka Utama, 2016.

Buku Putih Pertahanan Indonesia. Jakarta: Kemenhan, 2015.

\section{Peraturan Perundang-undangan:}

Pasal 27 ayat (3) UUD 1945.

Pembukaan UUD Tahun 1945 Alinea IV.

\section{Artikel Jurnal}

Lestari, Eta Yuni, Miftahul Jannah, dan Putri Karima Wardanai, "Menumbuhkan Kesadaran Nasionalisme Generasi Muda di Era Globalisasi Melalui Penerapan Nilai-Nilai Pancasila." Adil Indonesia Jurnal, Vol.1, No. 1, (2019).

Mahendra, Putu Ronny Angga dan I Made Kartika. "Memperkuat Kesadaran Bela Negara Dengan Nilai-nilai Pancasila dalam Perspektif Kekinian." Jurnal Pendidikan Kewarganegaraan Undiksha, Vol.8, No.3, (2020).

Nofriady, Johny, Yusuf, H.M. Halkis “Internalisasi Nilai-Nilai Bela Negara Dengan Pendekatan Binter di Wilayah Kodim 0618/BS Kota Bandung." Jurnal Program Studi Univeristas Pertahanan, (2018).

Nurhadianto. “Internalisasi Nilai-Nilai Pancasila Dalam Upaya Membentuk Pelajar Anti Narkoba." Jurnal Pendidikan Ilmu Sosial Vol.23, No. 2, (2014). 
Internalisasi Nilai-nilai Pancasila...

Nurizka, Rian dan Abdul Rahim. "Internalisasi Nilai-Nilai Pancasila Dalam Membentuk Karakter Siswa Melalui Budaya Sekolah." Elementary School Jurnal Pendidikan dan Pembelajaran Ke SD-an, Vol.7, No.1. (2020).

Warsito. “Internalisasi Nilai-Nilai Luhur Pancasila dalam Mata Kuliah Pendidikan Pancasila di Perguruan Tinggi." Jurnal (2017).

Widodo, Suwarno. "Implementasi Bela Negara Untuk Mewujudkan Nasionalisme." Jurnal Ilmiah Civis, Vol.1, No.1, (2011).

Yudhanegara, Firman. "Pancasila Sebagai Filter Pengaruh Globalisasi Terhadap Nilainilai Nasionalisme." Jurnal Ilmu Administrasi Negara, Vol.III, No.2, (2015).

\section{Website Internet}

Administrator, "Bela Negara dan Peran Serta Warga Negara Membangun Negeri",https://abnri.com/2020/03/20/bela-negara-dan-peran-serta-warganegara membangun-negeri-2/, diakses pada tanggal 31 Januari 2021, pukul 16:26 wib.

"Bab II Kajian Teori dan Kerangka Pemikiran", http://repository.unpas.ac.id/49952/5/BAB\%20II.pdf, diakses pada tanggal 31 Januari 2021, pukul 12:01 wib.

"Bab II Landasan Teori", http://etheses.iainkediri.ac.id/1314/3/932131714_BAB\%20II.pdf, diakses pada tanggal 31 Januari 2021, pukul 19:09 wib.

Dwi Zahrah Imania, https://www.researchgate.net/publication/330278649 Internalisasi_nilainilaiPancasilamelaluiPendidikan Pancasila dan kewarganegaraan dari masa ke masa, diakses pada tanggal 2 Februari 2021, pukul 17:11 wib.

Herwan Parwiyanto, "Pancasila Sebagai Sumber Nilai", http://herwaparwiyanto.staff.uns.ac.id/, diakses pada tanggal 9 Januari 2021, pukul 17:00 wib.

Mellynea Kezyta Negraheni, Internalisasi Nilai-Nilai Pancasila Pada Kalangan Pelajar, https://www.researchgate.net/publication/329484898 INTERNALISASI N ILAINILAI DALAM PANCASILA PADA KALANGAN PELAJAR, diakses pada tanggal 2 Februari 2021, pukul 17:11 wib.

http://bataviase.co.id/, diakses pada tanggal 28 Desember 2020, pukul 17:10 wib. 
"Pengertian Globalisasi", http://eprints.ums.ac.id/47004/3/BAB\%20I.pdf, diakses pada tanggal 28 Desember 2020, pukul 15:00 wib.

"Pentingnya Bela Negara Bagi Seluruh Rakyat Indonesia", https://pontianak.tribunnews.com/2019/10/06/pentingnya-bela-negarabagi-seluruh-rakyat-indonesia?page=all, diakses pada tanggal 31 Januari 2021, pukul 17:18 wib.

Rada, "Teknik Pengumpulan Data", https://dosenpintar.com/teknik-pengumpulandata/, diakses pada tanggal 29 Desember 2020, pukul 18:40 wib.

Sofyan Sauri, "Nilai "http://file.upi.edu/, diakses pada tanggal 21 Februari 2011.

Zulkarnain, "Pentingnya Kesadaran Bela Negara", https://www.kompasiana.com/mato/5791f46be3afbd7a09377e3c/pentingny a-kesadaran-bela-negara, diakses pada tanggal 24 Januari 2021, pukul 11:01 wib.

Zainal Abidin, Djoko Poernomo, Endang Iryanti, Lukman Arif, Buku Ajar Pendidikan Bela Negara, E-book http://lp3m.upnjatim.ac.id/download/materi\%20kuliah\%20bela\%20negara Bab-3-2014-Bela\%20Negara, diakses pada tanggal 31 Januari 2021, pukul 16:43 wib.

\section{Hasil Wawancara}

Hasil wawancara dengan Bapak Herly Hermawan, Pengacara di Kantor Arsen \& Co. Law firm, pada tanggal 29 Januari 2021 